Arq. Bras. Med. Vet. Zootec., v.64, n.1, p.9-14, 2012

\title{
Arthroscopical treatment of elbow joint disease
}

[Tratamento artroscópico de doenças da articulação do cotovelo]

C.M.F. Rezende, E.G. Melo, C. Malm, V.A. Gheller

Escola de Veterinária - Universidade Federal de Minas Gerais - Belo Horizonte, MG

\begin{abstract}
Elbow arthroscopy was performed in 30 dogs of different breeds. The procedure was performed bilaterally in 20 of these dogs, yielding a total of 50 joints. Different lesions were found, varying from cartilage fissures (8) to fragmentation (42) of medial coronoid process (FCP) of the ulna. Osteochondritis dissecans (OCD) of the humerus medial condyle was associated in four of them. All of these cases displayed varying degrees of synovitis. Osteoarthrosis (OA) in varying intensity was observed in 44 joints. The majority of cases were treated two to four months after the manifestation of clinical signs. Good clinical recovery occurred in dogs with minimal joint lesions, where these were diagnosed and treated within four weeks of the onset of clinical symptoms. Early diagnosis and arthroscopic treatment prevent osteoarthrosis and preserve locomotor function.
\end{abstract}

Keywords: Elbow, arthroscopy, dog, coronoid process fragmentation

\section{RESUMO}

Artroscopia do cotovelo foi realizada em 30 cães de diferentes raças, bilateral em 20, totalizando 50 articulações. Foram encontradas diferentes lesões que variavam de fissuras na cartilagem (8) a fragmentação (42). Osteocondrose dissecante (OCD) do côndilo medial do úmero estava associada à fragmentação do processo coronoide (FCP) medial da ulna em quatro casos. Em todas articulações verificou-se sinovite em graus variados. Osteoartrose $(O A)$ de diferentes intensidades foi observada em 44 articulações. O tratamento foi instituído na maioria dos casos, dois a quatro meses após a manifestação dos sinais clínicos. Recuperação clínica satisfatória ocorreu naqueles com mínima lesão articular, cujo diagnóstico e tratamento se fizeram dentro de quatro semanas após a manifestação clínica. O diagnóstico precoce e o tratamento artroscópico previne a osteoartrose e preserva a função locomotora.

Palavras-chave: Cotovelo, artroscopia, cão, processo coronoide

\section{INTRODUCTION}

A fragmented medial coronoid process (FCP) of the ulna is the most frequent cause of lameness in growing animals, among both large and giant breeds (Van Ryssen and Van Bree, 1997; Vermote et al., 2010). The injury is observed among different breeds, such as the German Shepherd, Golden Retriever, Saint Bernard, and Chow-chow (Grondalen, 1981; Flückiger, 1992; Durmus and Han, 2010), but is particularly prevalent among the Rottweiler, Labrador, and
Bernese (Olsson, 1983; Lewis et al., 1989). It is considered a hereditary condition influenced by the environment (Guthrie and Pidduck, 1990), with males being affected more often than females (Olsson 1983, Flückiger, 1992; Padgett et al., 1995).

The FCP is characterized by fragmentation of the cartilage and the subcondylar bone, as well as varying degrees of cartilage erosion (Beale et al., 2003, Cook and Cook, 2009). Its pathophysiology is not well defined, but is

Recebido em 4 de março de 2011

Aceito em 28 de novembro de 2011

E-mail: marilia@vet.ufmg.br

E-mail: Cleuzaufmg@gmail.com 
considered a sign of osteochondrosis (Olsson, 1983; Van Ryssen and Van Bree, 1997). Factors such as trauma, mechanical overload (Grondalen, 1981) and joint incongruence have been suggested to contribute to the etiopathogeny (Beale et al., 2003).

The clinical symptoms can occur after maturity, but the condition starts during the growth phase. Manifestation can be unilateral or bilateral, with bilateral occurrence being more common (Olsson, 1983; Cook and Cook, 2009) and reported three times more often in males (Flückiger, 1992; Lewis et al., 1989).

The diagnosis is made based on clinical and radiographic exams, computed tomography (CT) and magnetic resonance (MRI) (Van Ryssen and Van Bree, 1994; Fitzpatrick et al., 2009). Radiography is routinely employed to examine patients, although the information this technique yields is limited, especially during the initial phase of FCP.

MRI and CT are more accurate exams (Braden et al., 1994; Van Bree and Van Ryssen, 1994; Van Ryssen and Van Bree, 1997; Beale et al., 2003), but displaced fragments may go unnoticed (Van Ryssen and Van Bree, 1997). Therefore, arthroscopy is the method of choice for the definitive diagnosis and treatment of FCP (Beale et al., 2003). Its use is recommended for all young large-breed dogs with clinical signs of elbow lesion including those not showing radiographic alterations (Van Bree and Van Ryssen, 1994). It is a relatively simple and fast procedure, after overcoming the challenge posed by limited joint space (Beale et al., 2003).

The objective of this study is to report the use of arthroscopy in the treatment of FCP in dogs and to describe the lesions found.

\section{MATERIALS AND METHODS}

Thirty dogs underwent arthroscopy (Table 1). The selection criteria was based on clinical and radiological signs related to the elbow joint, such as outward rotation of the paw with the elbow held close into the body, lameness, a painful response to manipulation, especially on external rotation and hyperextension, reduced range of flexion and extension, crepitus, joint fluid effusion.

Table 1. Breed and gender distribution of $30 \mathrm{dogs}$ with fragmentation of the medial coronoid process

\begin{tabular}{lccc}
\hline Breed & Male & Female & Total \\
\hline Labrador & 10 & 2 & 12 \\
Rottweiler & 6 & 3 & 9 \\
English Bulldog & 2 & - & 2 \\
Mastiff & 1 & - & 1 \\
German Shepherd & 1 & - & 1 \\
Brazilian Mastiff & - & 1 & 1 \\
Bernese & 1 & - & 1 \\
Chow-chow & 1 & - & 1 \\
Golden Retriever & 2 & - & 2 \\
Total & 24 & 6 & 30 \\
\hline
\end{tabular}

Radiography of both elbows was done in craniocaudal and medio-lateral flexed positions. The presence of periarticular osteophytes, bone sclerosis and the appearance of the ulna medial coronoid process were evaluated (Hornoff et al., 2000). The arthroscopy recommendation was made based on clinical signs and physical examination that were or were not associated with the radiographic findings. Suspicion of FCP was based on the radiographic indefinition of the coronoid process or evidence of ostheophytosis and the elimination of all other known causes of arthritis. The condition was considered to be unilateral based on absence of findings on physical examination and on radiographic changes. The animals underwent arthroscopy via the medial approach under general anesthesia (inhalation) (Isophorine- Cristália Prod. Quím. Farm. Ltda, Itapira, São Paulo, Brazil) (Van Ryssen et al., 1993; Beale et al., 2003). The joint distension was maintained with an arthropump, (Arthropump- Karl Storz Endoscope, Tuttling, Germany) with a flow of 300 to $400 \mathrm{~mL} / \mathrm{min}$ and pressure of 60 to $100 \mathrm{mmHg}$. In suspected cases of OCD, the arthroscope (Arthropump-Karl Storz Endoscope, Tuttling, Germany) was placed 
slightly more caudally. In the presence of a coronoid fissure, the fragment was released with a hypodermic needle and the adhesions were released with a hook or arthoscopic knife (Arthropump Karl Storz endoscope, Tuttling, Germany).

The joint cartilage and the synovial membrane were evaluated according to color, deterioration, erosions, and proliferations. The cartilage lesions were evaluated based on the modified Outerbridge classification.

\section{RESULTS}

All of the dogs showed mild, moderate or severe reaction to the elbow on physical examination. The age range affected was four months to four years; 25 dogs were less than 12 months old. The symptoms in three animals at four and five months of age were reported. The majority (27 cases) showed clinical signs during the growth phase (4-9 months). The treatment was used in 25 dogs between 5-12 months of age, in three dogs between 15-17 months, and in two animals at three and four years, respectively. Arthroscopy was performed in the majority of the dogs, 2 to 4 months after the onset of clinical symptoms.

Joint effusion was observed in both chronic and acute cases. It was pronounced in the acute cases associated with OCD of the medial humerus condyle. Among seven dogs with joint effusion, four were Labradors aged 6-7 months, which had shown symptoms for 1-2 months.

Most of the joints (88\%) showed mild to severe radiological signs. The changes were abnormal contour or poor visualization of the medial coronoid process, osteophyte production and subtrochlear sclerosis of the sublunar notch of the ulna.

The condition was bilateral in $20 \mathrm{dogs}$ and unilateral in 10, yielding a total of 50 joints. The bilateral cases were treated at the same time, as were those associated with OCD. Mild to severe OA was present in 44 joints.
Among 30 dogs, 24 were male, representing $80.0 \%$ of the affected population. Regarding the breeds, the Labrador represented $33.3 \%$ of the population, followed by the Rottweiler (20\%).

Lesions of the medial coronoid process were identified in all joints.

Numerous variations was observed in the appearance of the fragmentation, including a case of fissure in the cartilage similar to a mosaic (Fig. 1), non-displaced fragmentations (fissure) (Fig. 2); free fragments in the joint (Fig. 3); multiple fragments (Fig. 4); and bone fragments associated with soft white tissue (chondromalacia), cartilage fibrilation. In four joints, FCP was associated with OCD of the humerus medial condyle (Fig. 5). Articular cartilage erosion by friction on the medial humerus condyle (Fig. 6) exhibited different intensities, which varied with the chronicity of the case. In one dog, FCP, humerus condyle OCD, and deep erosion of the radius adjacent to the coronoid process were all observed (Fig. 5).

Synovitis and hypertrophy of the villi were observed in different degrees in all of the joints. Moderate to accentuated $\mathrm{OA}$ was found in chronic cases, with the condition generally more serious in animals older than 18 months that have large body mass $(>30 \mathrm{~kg})$.

Upon physical examination clinical improvement was observed after 4-6 weeks.

The technical difficulties during the procedure included the small joint area, vision obstructed by villi, hemorrhages, and adherence of bone fragments to the annular or medial collateral cases. There were also small iatrogenic lesions without post-surgical relevance. These included cartilage surface lesions created by the puncture needle, grasping forceps or arthroscopic blade. An accumulation of periarticular fluid occurred in some animals where the surgical procedures took longer and required a higher number of entries at the instrument portal. This fluid was reabsorbed in 24 hours. 


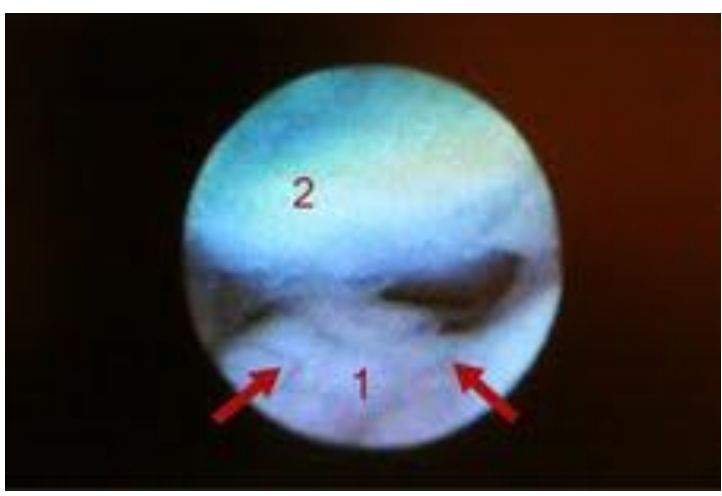

Figure 1. Right elbow - mosaic-type fissure (arrows): 1 - medial coronoid process, 2 - humerus condyle.

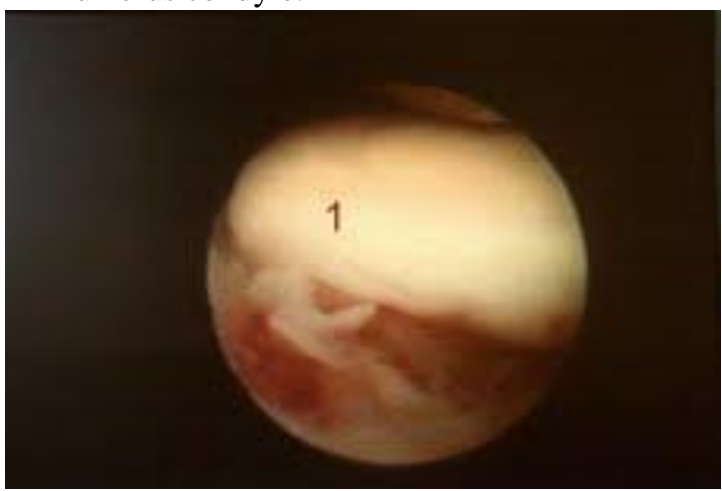

Figure 3. Left elbow: free fragment.

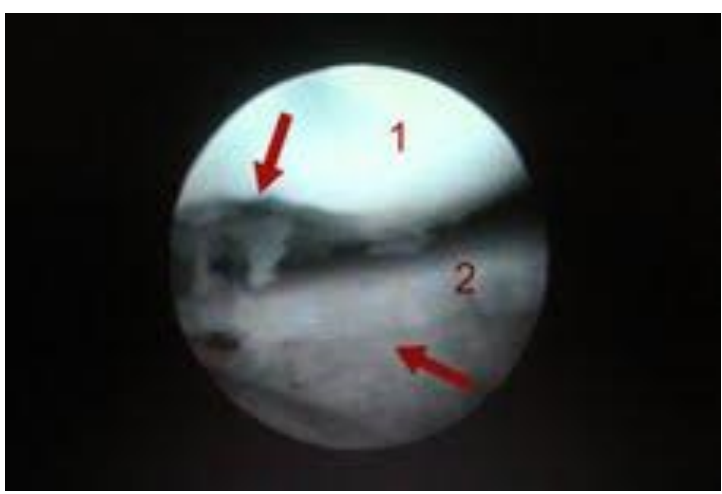

Figure 5. Right elbow: 1 - humerus condyle - OCD (arrow) 2 - radial head - erosion (arrow).

\section{DISCUSSION}

Arthroscopy is quickly becoming more popular in the veterinary field for both the diagnosis and the treatment of canine joint disorders. Arthroscopy of the elbow represents a great advance in veterinary orthopedics, given the high frequency of joint disorders. It allows for an early diagnosis and the treatment of osteochondral lesions (Van Ryssen and Van Bree

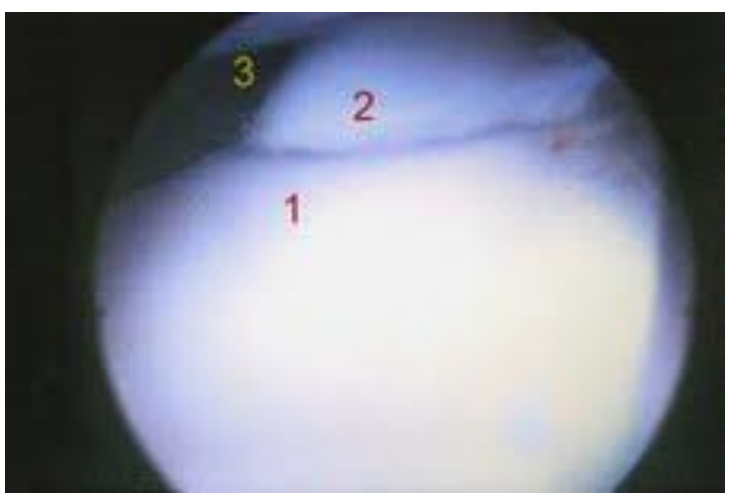

Figure 2. Left elbow - fissure: 1 - medial coronoid process, 2 - non-displaced fragment (fissure), 3 - humerus condyle.

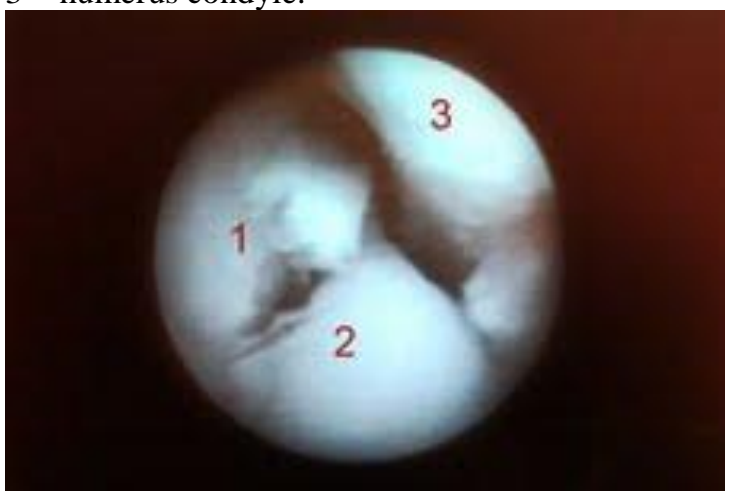

Figure 4. Right elbow: 1 and $2-$ multiple fragments, 3 - Humerus condyle.

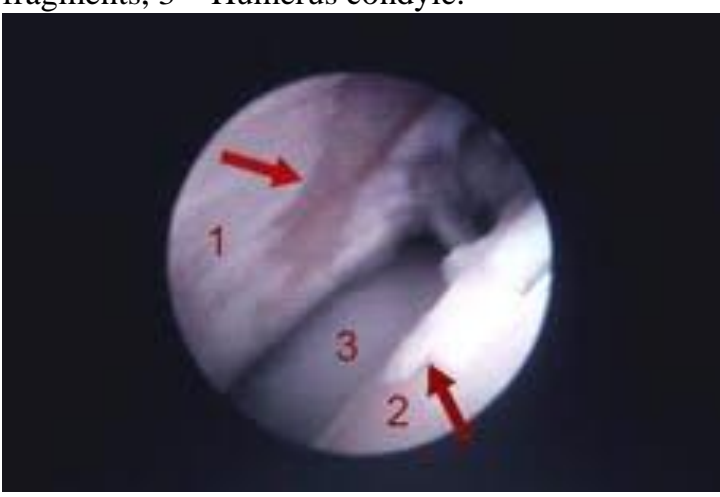

Figure 6. Left elbow: 1 - humerus condyle: erosion by friction (arrow), 2 - coronoid process.

1997; Beale et al., 2003; Cook and Cook, 2009), which represent a serious locomotor problem in dogs of different breeds and sizes (Olsson, 1983; Vermote et al., 2010).

In spite of the relatively low number of dogs in this study, the prevalence of FCP in males was remarkable (Lewis et al., 1989; Padgett et al., 1995) (Table 1), higher than that reported by Flückiger (1992) and in relation to condyle OCD. 
Moreover, the frequency of FCP in Labradors is noteworthy. Considering lesion heredity (Guthrie and Pidduck, 1990), it is necessary that control measures be taken as the resulting AO can lead to locomotion dysfunction throughout life.

Our observation of 50 FCP and 4 OCD is higher than mentioned in the literature (Van Ryssen and Van Bree, 1997) and confirms the predominance of FCP.

The arthroscopic treatment is relatively simple and fast, especially in acute cases, where the fragment can be easily removed without interference of the villi or adhesions. Postoperative recovery is fast and the prognosis is favorable when the treatment is done early (Van Bree and Van Ryssen, 1994; Van Ryssen and Van Bree, 1997; Beale et al., 2003), before OA development. In chronic cases, the surgical time may be increased because of the need for the partial removal of villi, bone curettage, release of adhesions and due to the difficulty in identifying structures, as in the case of multiple fragmentation and the presence of soft spongy tissue (Van Ryssen and Van Bree, 1997; Vermote et al., 2010).

Although they were a minority, animals at three and four years of age also showed mild clinical improvement after the arthoscopic treatment. Moderate to severe osteoarthritis was already present, associated with isolated or multiple fragments devitalized in a white, soft, spongy tissue (Van Ryssen and Van Bree, 1997; Cook and Cook, 2009). The surgical treatment provided satisfactory clinical improvement, mainly in the early conditions.

Although clinical symptoms started in some animals at 4-5 months and in others in the adult phase, the highest incidence was between 6 and 7 months (during the growth phase) (Olsson, 1983).

The search for an early diagnosis has been gradually increasing with the dissemination of arthroscopy because of the reduced morbidity. Good clinical recovery occurred in the animals which were in the initial phase of the process, with minimal arthroscopic joint alterations and no visualized radiographic changes. The definitive diagnosis of FCP on conventional radiographs poses some problems because the location of the fragment(s) means that it is usually superimposition of the others structures. However, clinical improvement was observed in each of the animals that were submitted to the intervention.

In addition to the detailed view of joint structures (Van Bree and Van Ryssen, 1994; Beale et al., 2003), arthroscopy enables the evaluation of AO (Borges et al., 2008) and the establishment of a prognosis.

The medial approach (Van Ryssen et al., 1993; Beale et al., 2003) permits direct access to the medial coronoid process, detailed identification of the joint structures, and treatment of lesions. These characteristics are ideal for the interventions performed in this study (Van Ryssen and Van Bree, 1997; Beale et al., 2003).

In the majority of cases, including the most recent, FCP was associated with superficial or deep lesions in the medial condyle cartilage (Van Ryssen and Van Bree, 1997; Beale et al., 2003, Fitzpatrick et al., 2009). The severity of these lesions varied according to the chronicity of the case, independently of the presence of fissures or free fragments. In the acute cases, a localized synovial reaction was visible, with the preservation of the bright white appearance of the cartilage adjacent to the coronoid lesion.

As determined by the clinical results obtained and with the emergence of arthroscopy, FCP should be treated at any phase of the process since the removal of the intra-articular fragments eliminates the mechanical irritation (Van Ryssen and Van Bree, 1997; Cook and Cook, 2009) and contributes to the control of OA. In addition, the arthroscopic technique does not aggravate the clinical condition.

In contrast to OCD incidence (Olsson, 1983), the frequency of erosions induced by friction in the humerus medial condyle cartilage (Van Ryssen and Van Bree, 1997; Beale et al., 2003; Vermonte et al., 2010) is high; these erosions can be confused with OCD. A surgeon who is inexperienced in performing arthroscopy has to be aware of the characteristics of each lesion. The erosions are more extensive and superficial and can be present in the acute cases. This further reinforces the need for early intervention. 
Arthroscopy is a minimally invasive procedure recommended for the early diagnosis and treatment of FCP, which is an important and frequent cause of lameness in young animals.

Intra-articular fragment removal can be a simple and fast procedure, but the challenge for the surgeon is the post-surgical management of the associated OA (Beale et al., 2003). Early diagnosis and treatment are good options for FCP management and consequently for OA prevention.

\section{CONCLUSIONS}

The arthroscopic treatment of FCP means reduced morbidity and produced better clinical results. Because of these, any clinical suspicion of the lesion justifies the use of arthroscopy for confirmation and early treatment.

\section{ACKNOWLEDGEMENTS}

We thank Mauricio Silva Gino, $\mathrm{PhD}$, professor at the Escola de Belas Artes - Universidade Federal de Minas Gerais, for elaborating the images.

\section{REFERENCES}

BEALE, B.S.; HULSE, D.A.; SCHULTZ, K.S. et al. Small Animal Arthroscopy. Philadelphia, P.A.: Saunders, 2003. 231 p.

BORGES, N.F.; REZENDE, C.M.F.; MELO E.G. et al. Videoarthroscopy of the femoral-tibial-patellar joint in dogs after sectioning of the cranial cruciate ligament guided by arthroscopy. Arq. Bras. Med. Vet. Zootec., v.60, p.1035-1044, 2008.

BRADEN, T.D.; STICKLE, R.L.; DEJARDIN, L.M.; MOSTOSKY, U.V. The use of computed tomography in fragmented coronoid disease. A case report. Vet. Comp. Orthopaedics and Traumatology, v.7, p.40-44, 1994.

COOK, J.L. and COOK, C.R. Bilateral shoulder and elbow arthroscopy in dogs with forelimb lamness: diagnostic findings and treatment outcomes. Vet. Surg., v.38, p.224-232, 2009.

DURMUS, A.S. and HAN, M.G. Elbow dysplasia in German shepherd in Turkey. J. Anim. Vet. Adv., v.9, p.1614-1616, 2010.
FITZPATRICK, N.; SMITH, T.J.; EVANS, R.B.; YEADON, R. Radiographic and arthrocopic findings in the elbow joints of 263 dogs with medial coronoid disease. Vet. Surg., v.38, p.213-223, 2009.

FLÜCKIGER, M. Ellbogendysplasie (ED) beim Hund. Schweiz. Arch. Tierheilk, v.134, p.261-271, 1992.

GRONDALEN, J. Arthrosis of the elbow joint of young rapidly growing dogs. V. A pathoanatomical investigation. Nord. Vet. Med., v.33, p.1-16, 1981.

GUTHRIE, S. and PIDDUCK, H.G. Heritability of elbow osteochondrosis within a closed population of dogs. J. Small Anim. Pract., v.31, p.93-96, 1990.

HORNOF, W.J.; WIND, A.P.; WALLACK, S.T. et al. Canine elbow dysplasia: the early radiographic detection of fragmentation of the coronoid process. Vet. Clin. North Am., v.30, p.257-266, 2000.

LEWIS, P.D.; PARKER, R.B.; HAGER, D.A. Fragmented medial coronoid process of the canine elbow. Comp. Contin. Educ. Pract. Vet., v.11, p.703716, 1989

OLSSON, S.E. The early diagnosis of fragmented coronoid process and osteochondritis dissecans of the canine elbow joint. J. Am. Anim. Hosp. Assoc., v.19, p.616-623, 1983.

PADGETT, G.A.; MOTOSKY, U.V.; PROBST, C.W. et al. The irrheritance of osteochondritis dissecans and fragmented coronoid process of the Elbow joint in Labrador retrievers. J. Am. Anim. Hosp. Assoc., v.31, p.327-330, 1995.

Van RYSSEN, B. Van BREE, H., SIMOENS, P. Elbow arthroscopy in clinically normal dog. Am. $J$. Vet. Res., v.54,p 191-198, 1993

Van BREE, H. and Van RYSSEN, B. Diagnostic imaging of the canine elbow joint including. Radiology, arthroscopy and computed tomography (CT). Vet. Rad. Ultras., v.35, p.248, 1994.

Van RYSSEN, B. and Van BREE H. Arthroscopic findings in 100 dogs with elbow lameness. Vet. Rec., v.140, p.360-362, 1997.

VERMOTE， K.A.G.; BERGENHUYZEN， A.L.R.; GIELEN, I. et al. Elbow lameness in dogs of six years and older: arthroscopic and imaging findings of medial coronoid disease in 51 dogs. Vet. Comp. Orthop. Traumatol., v.23, p.43-50, 2010. 